\title{
JOURNAL OF APPLIED PROBABILITY VOLUME 46 (2009): INDEX
}

AgUech, R. Limit theorems for random triangular urn schemes $\ldots \ldots \ldots \ldots \ldots \ldots \ldots \ldots \ldots \ldots$

Ano, K. see Kurushima, A.

Applebaum, D. AND SiaKalli, M. Asymptotic stability of stochastic differential equations driven

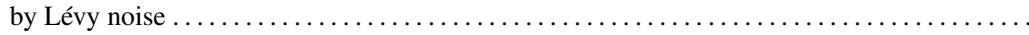

ASMUSSEN, S. Importance sampling for failure probabilities in computing and data transmission ..

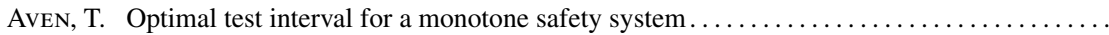

Badescu, A. L., Cheung, E. C. K. And Landriault, D. Dependent risk models with bivariate

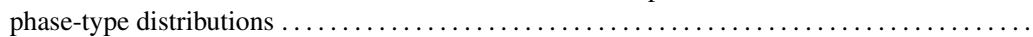

Baeumer, B., Meerschaert, M. M. and Nane, E. Space-time duality for fractional diffusion... BArbour, A. D. see Socoll, S. N.

Barndorff-Nielsen, O. E., Corcuera, J. M., Podolskij, M. and Woerner, J. H. C. Bipower variation for Gaussian processes with stationary increments $\ldots \ldots \ldots \ldots \ldots \ldots \ldots \ldots$

BAurdoux, E. J. Last exit before an exponential time for spectrally negative Lévy processes ..... Behrens, S. ANd Löwe, M. Moderate deviations for word counts in biological sequences......... BENDER, C. AND MARQUARDT, T. Integrating volatility clustering into exponential Lévy models...

Bercu, B., Cénac, P. and Fayolle, G. On the almost sure central limit theorem for vector martingales: convergence of moments and statistical applications $\ldots \ldots \ldots \ldots \ldots \ldots \ldots$

BertaCCHI, D. AND ZuCCA, F. Approximating critical parameters of branching random walks .... .

BónA, M. AND FlaJolet, P. Isomorphism and symmetries in random phylogenetic trees .........

Bordenave, C., Foss, S. And Shneer, V. A random multiple-access protocol with spatial interactions

Bose, A., Dasgupta, A. And Maulik, K. Strong laws for balanced triangular urns ............

BRITTON, T. AND LindHolm, M. The early stage behaviour of a stochastic SIR epidemic with

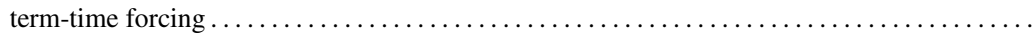

Bruss, F. T. AND Swan, Y. C. A continuous-time approach to Robbins' problem of minimizing the

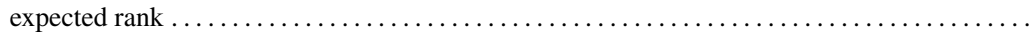

Burkschat, M. Systems with failure-dependent lifetimes of components $\ldots \ldots \ldots \ldots \ldots \ldots \ldots$

CAI, K. -Y. see Wu, X. -Y.

ČeKanavičIUs, V. see PeKöz, E. A.

CÉNAC, P. see BERCU, B.

Cha, J. H. AND Finkelstein, M. On a terminating shock process with independent wear increments

Chen, Y. -T., LeE, C. -F. AND Sheu, Y. -C. An integral-equation approach for defaultable bond

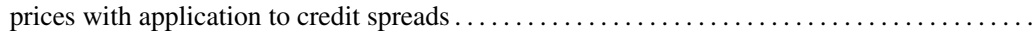

Cheung, E. C. K. And Landriault, D. Perturbed MAP risk models with dividend barrier strategies

\section{- see BADESCU, A. L.}

Christofides, T. C. And Vaggelatou, E. Bounds for the distance between the distributions of sums of absolutely continuous i.i.d. convex-ordered random variables with applications ....

Coletti, C. F., Fontes, L. R. G. And Dias, E. S. Scaling limit for a drainage network model..... Corcuera, J. M. see BARndorfF-Nielsen, O. E.

Costa, O. L. V. And Dufour, F. The vanishing discount approach for the average continuous control

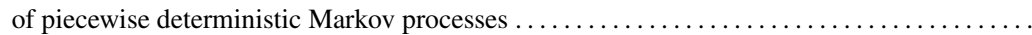

Covo, S. On approximations of small jumps of subordinators with particular emphasis on a Dickman-

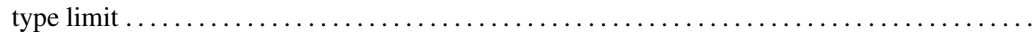

Dasgupta, A. see Bose, A.

Deligiannidis, G., Le, H. And Utev, S. Optimal stopping for processes with independent

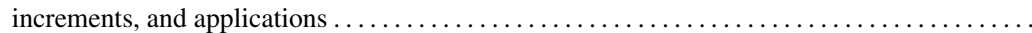


Delmas, J. -F. AND Jourdain, B. Does waste recycling really improve the multi-proposal Metropolis-

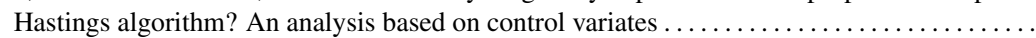

Dhariyal, I. D. see MisRa, N.

Dias, E. S. see Coletti, C. F.

Diasparra, M. A. AND Romera, R. Bounds for the ruin probability of a discrete-time risk process Dong, Z. see Wu, X. -Y.

Draief, M., Ganesh, A. and Massoulié, L. Exponential random graphs as models of overlay

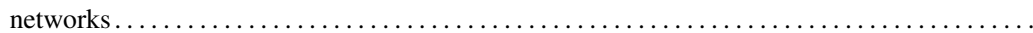

Dufour, F. see Costa, O. L. V.

EKström, E. AND WANnTORP, H. Optimal stopping of a Brownian bridge $\ldots \ldots \ldots \ldots \ldots \ldots \ldots$

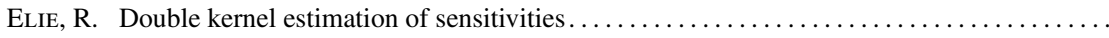

FAyOlle, G. see Bercu, B.

Fei, J. see Feinberg, E. A.

FeInBERG, E. A. AND Fei, J. An inequality for variances of the discounted rewards...........

Finkelstein, M. see CHA, J. H.

Flajolet, P. see Bóna, M.

Fontes, L. R. G. see Coletti, C. F.

Foss, S., Korshunov, D. AND Zachary, S. Convolutions of long-tailed and subexponential

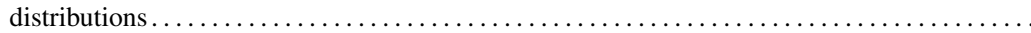
see Bordenave, C.

Ganesh, A. see Draief, M.

GrüBEL, R. AND HitczenKo, P. Gaps in discrete random samples $\ldots \ldots \ldots \ldots \ldots \ldots \ldots \ldots \ldots$

Gupta, N. see Misra, N.

HaO, X., TANG, Q. AND WeI, L. On the maximum exceedance of a sequence of random variables

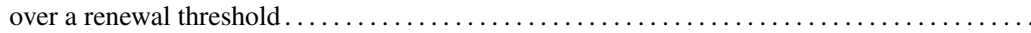

HARTVIGSEN, D. The action gambler and equal-sized wagering $\ldots \ldots \ldots \ldots \ldots \ldots \ldots \ldots \ldots$

Heinzmann, D. Extinction times in multitype Markov branching processes . . . . . . . . . . . .

HernándeZ-Lerma, O. see Jasso-Fuentes, H.

HitCZENKo, P. see GRÜBEL, R.

Holst, L. On consecutive records in certain Bernoulli sequences $\ldots \ldots \ldots \ldots \ldots \ldots \ldots \ldots \ldots$

HosaKa, K. An alternative condition for stochastic domination $\ldots \ldots \ldots \ldots \ldots \ldots \ldots \ldots \ldots \ldots$

Huillet, T. ANd MöHle, M. Duality and asymptotics for a class of nonneutral discrete Moran models

HuRD, T. R. AND KuzNETsov, A. On the first passage time for Brownian motion subordinated by a

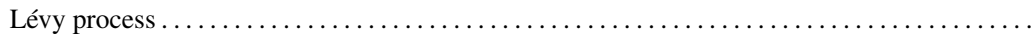

JACKA, S. Markov chains conditioned never to wait too long at the origin $\ldots \ldots \ldots \ldots \ldots \ldots \ldots$

JANSON, S. AND Petersson, N. The integral of the supremum process of Brownian motion ....... .

JASIŃSKI, K., NAVARRo, J. AND RYCHLIK, T. Bounds on variances of lifetimes of coherent and mixed

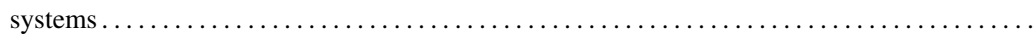

Jasso-Fuentes, H. AND Hernández-Lerma, O. Blackwell optimality for controlled diffusion

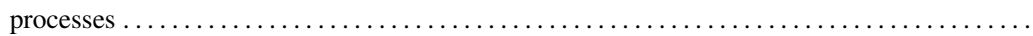

Jourdain, B. see Delmas, J. -F.

Karpowicz, A. Double optimal stopping in the fishing problem $\ldots \ldots \ldots \ldots \ldots \ldots \ldots \ldots \ldots$

KeLla, O. On growth-collapse processes with stationary structure and their shot-noise counterparts

Kochar, S. AND XU, M. Comparisons of parallel systems according to the convex transform order

Korshunov, D. see Foss, S.

Kurushima, A. AND Ano, K. Maximizing the expected duration of owning a relatively best object in a Poisson process of rankable observations . . . . . . . . . . . . . . . . . . . . . . .

Kuznetsov, A. see Hurd, T. R.

Kyprianou, A. E. AND Zhou, X. General tax structures and the Lévy insurance risk model ......

LagnouX-Renaudie, A. A two-step branching splitting model under cost constraint for rare event

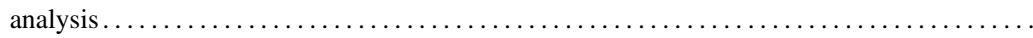

Landriault, D. see Badescu, A. L. and Cheung, E. C. K.

$1201-1208$

1198-1200

$866-893$

181-198

$812-826$

$593-600$

894-908

$372-391$

415-428

363-371

342-352

LE, H. see Deligiannidis, G.

LeE, C. -F. see Chen, Y. -T.

LI, H. AND Sun, Y. Tail dependence for heavy-tailed scale mixtures of multivariate distributions . .

LI, Y. A weak limit theorem for generalized Jiřina processes 
Liggett, T. M. AND Schinazi, R. B. A stochastic model for phylogenetic trees

Lin, G. D. and Stoyanov, J. The logarithmic skew-normal distributions are moment-indeterminate

LindHOLM, M. see BRITTON, T.

LIU, K. see Wu, X. -Y.

LIU, R. -L., REN, Y.-X. AND Song, R. $L \log L$ criterion for a class of superdiffusions

LOEFFEN, R. L. An optimal dividends problem with a terminal value for spectrally negative Lévy

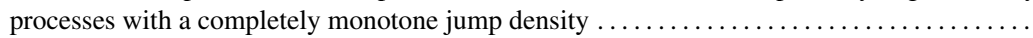

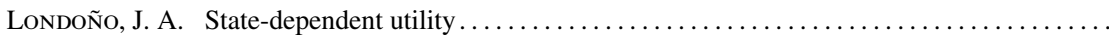

LöWE, M. see BEHRENS, S.

Ma, S. And Molina, M. Two-sex branching processes with offspring and mating in a random

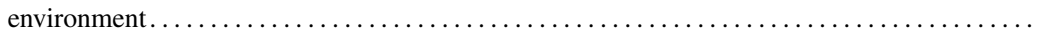

Marquardt, T. see Bender, C.

Massoulié, L. see Draief, M.

Maulik, K. see Bose, A.

Meerschaert, M. M. see Baeumer, B.

Mendivil, F., Shonkwiler, R. AND Spruill, M. C. Geometric convergence of genetic algorithms

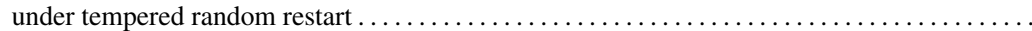

Misra, N., Dhariyal, I. D. and Gupta, N. Optimal allocation of active spares in series systems and comparison of component and system redundancies

960-974

Möhle, M. see Huillet, T.

Molina, M. see MA, S.

NAKATA, T. Necklace processes via Pólya urns

NANe, E. see BAEUMER, B.

NAVARRO, J. see JASIŃSKI, K.

Niemiro, W. AND Pokarowski, P. Fixed precision MCMC estimation by median of products of

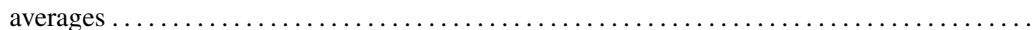

Pardoux, E. And Salamat, M. On the height and length of the ancestral recombination graph ...

Peköz, E. A., Röllin, A., Čekanavičius, V. and Shwartz, M. A three-parameter binomial

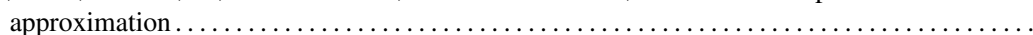

Petersson, N. see Janson, S.

PIAU, D. Asymptotics of iterated branching processes

PodolskiJ, M. see BARndorfF-Nielsen, O. E.

Pokarowski, P. see Niemiro, W.

Pósfai, A. Poisson approximation in a Poisson limit theorem inspired by coupon collecting ......

ReN, Y.-X. see LIU, R. -L.

Röllin, A. see PeKöz, E. A.

Romera, R. see Diasparra, M. A.

RYCHLIK, T. see JASIŃSKI, K.

Salamat, M. see Pardoux, E.

SchinAZI, R. B. see LiggetT, T. M.

Sheu, Y. -C. see Chen, Y. -T.

ShneER, V. see Bordenave, C.

Shonkwiler, R. see Mendivil, F.

Shwartz, M. see Peköz, E. A.

Siakalli, M. see Applebaum, D.

Socoll, S. N. AND BARBour, A. D. Local limit approximations for Markov population processes.

Song, R. see LiU, R. -L.

Spruill, M. C. see Mendivil, F.

Squillante, M. S. see Van Leeuwaarden, J. S. H.

Stoyanov, J. see Lin, G. D.

Sun, Y. see LI, H.

SWAN, Y. C. see Bruss, F. T.

TAMAKI, M. Optimal choice of the best available applicant in the full-information models ........

TANG, Q. see HAO, X.

TEhranchi, M. R. Asymptotics of implied volatility far from maturity

Upadhye, N. S. see Vellaisamy, P. 
Utev, S. see Deligiannidis, G.

Vaggelatou, E. see Christofides, T. C.

Van Leeuwaarden, J. S. H., Squillante, M. S. and Winands, E. M. M. Quasi-birth-and-death processes, lattice path counting, and hypergeometric functions $\ldots \ldots \ldots \ldots \ldots \ldots \ldots \ldots$

Vellaisamy, P. AND UPADHYE, N. S. On the sums of compound negative binomial and gamma

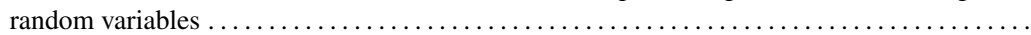

WANG, Y. see XING, X.

WANNTORP, H. see EKSTRÖM, E.

WEI, L. see HAO, X.

Winands, E. M. M. see Van LeeuwaArden, J. S. H.

Woerner, J. H. C. see BARndorfF-Nielsen, O. E.

WU, X. -Y., Dong, Z., LIU, K. AND CAI, K. -Y. On the degree sequence and its critical phenomenon of an evolving random graph process

XI, F. AND Yin, G. Asymptotic properties of a mean-field model with a continuous-state-dependent

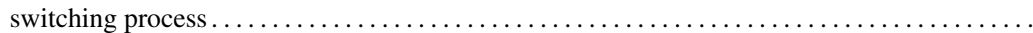

XING, X., ZHANG, W. AND WANG, Y. The stationary distributions of two classes of reflected OrnsteinUhlenbeck processes

XU, F. A central limit theorem associated with the transformed two-parameter Poisson-Dirichlet distribution

$392-401$

XU, M. see KOCHAR, S.

Yam, S. C. P., Yung, S. P. And Zhou, W. Two rationales behind the 'buy-and-hold or sell-at-once'

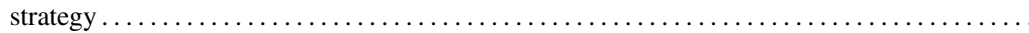

YAP, V. B. Similar states in continuous-time Markov chains

$651-668$

$497-506$

YIN, G. see XI, F.

YU, Y. Stochastic ordering of exponential family distributions and their mixtures

$244-254$

Yung, S. P. see YAM, S. C. P.

ZACHARY, S. see Foss, S.

Zhang, S. AND Zhang, X. On the transition law of tempered stable Ornstein-Uhlenbeck processes

Zhang, W. see XING, $\mathrm{X}$.

ZHANG, X. see ZHANG, S.

ZHENG, Q. Remarks on the asymptotics of the Luria-Delbrück and related distributions

ZHOU, W. see YAM, S. C. P.

Zhou, X. see Kyprianou, A. E.

Zucca, F. see BerTacchi, D. 